\title{
Communication, Leadership, and Job Satisfaction: Perspectives on Supervisor-Subordinate Relationships
}

\author{
Kathleen Czech \& G. L. Forward \\ Point Loma Nazarene University, Department of Communication \& Theatre, USA \\ Correspondence: G. L. Forward, Point Loma Nazarene University, Department of Communication \& Theatre, \\ 3900 Lomaland Drive, San Diego, CA 92106, USA. E-mail: GLForward@pointloma.edu
}

Received: April 10, 2013 Accepted: May 3, 2013 Available online: July 10, 2013

doi:10.11114/smc.v1i2.122 URL: http://dx.doi.org/10.11114/smc.v1i2.122

\begin{abstract}
In an era when leadership is much studied and little understood (Tourish \& Barge, 2010), and when job satisfaction has reached an all-time low (Gibbons, 2010), investigating factors that contribute to job and relationship satisfaction, as well as more effective leadership, becomes a critical task. This project asked 154 people employed fulltime to evaluate their work supervisor in terms of specific communication behaviors, perceived leader effectiveness, and their own levels of relational and job satisfaction. Gibb's (1961) theory of supportive and defensive communication provided the conceptual lens used to explicate the impact of communication behaviors on specific personal and organizational outcomes. Statistical analysis highlighted the discursive nature of workplace interaction by uncovering strong, predictive relationships between the positive behaviors of spontaneity and empathy and worker perceptions of supervisor effectiveness, relational satisfaction, and employee job satisfaction. Likewise, perceptions of supervisor leadership style are instantiated in these same communication behaviors suggesting that leadership is indeed a communication phenomenon. Last, t-tests revealed that supervisors rated higher in effectiveness and higher in relational satisfaction utilized all six of Gibb's supportive communication behaviors more, and all six defensive behaviors less, than their more negatively evaluated peers.
\end{abstract}

Keywords: defensive and supportive communication, leadership communication, employee job satisfaction, supervisor-subordinate communication, supervisor effectiveness, relationship satisfaction

\section{Introduction}

Numerous researchers have established the significance of superior-subordinate communication as a crucial element in an organization's continuing success (Daniels, Spiker, \& Papa, 1997; Kassing, 2008; Lee \& Jablin, 1995; Schnake, Dumler, Cochran, \& Barnett, 1990). This is relevant because effective superior-subordinate communication has been linked to a number of positive outcomes, including higher levels of cooperation and employee job satisfaction (Madlock, 2008). In an era of economic and organizational upheaval, ineffectual leadership (Tourish \& Barge, 2010), and all time lows in job satisfaction (Gibbons, 2010), investigating factors that contribute to job and relationship satisfaction and more effective leadership is crucial.

In 1961, Jack Gibb published an essay that identified highly specific supportive and defensive communication behaviors predicated on his voluminous observations of small group member interaction. Gibb's communication construct has been applied to numerous communication sub-disciplines and is prevalent in communication textbooks of all types (Forward, Czech, \& Lee, 2011). However, despite its popularity, Gibb's theory has generated only modest empirical investigation for two reasons. First, Gibb (1961) himself never created a survey instrument to test or validate his theory. Organizational and group communication studies were in their relative infancy in 1961 and statistical analysis was not always presumed to be necessary, especially for those who approached the topic from a "speech" or rhetorical perspective (Tompkins \& Redding, 1988). Secondly, by the time a survey instrument became readily available more than 20 years later (Costigan \& Schmeidler, 1984), the concept of supportive and defensive communication had taken a functionalist and skills-oriented turn more applicable to practitioners than theoreticians (Redding, 1985).

The contribution of our study therefore is threefold. First, we will empirically test Gibb's defensive and supportive communication construct and assess its usefulness in analyzing the supervisor-subordinate relationship in the workplace. Secondly, by assessing the theory and contributing empirical data, we hope to gain insight into the 
specific communication behaviors that contribute to effective supervisor-subordinate communication, leadership, relationships, and job satisfaction. Lastly, Gibb's theory, and this research, highlights the discursive nature of leadership. In their critique of the traditional, functionalist approach, Tourish and Barge (2010, p. 323) argue that the study of leadership should become "an exploration of leader and message effects" as leaders and the led "exercise a reciprocal influence" on each other. The level of specificity inherent in Gibb's theory provides an opportunity to examine the effects of voice, words, and discourse in the workplace.

\section{Literature Review}

\subsection{Supportive and Defensive Communication}

Organizational communication researchers have studied numerous interaction behaviors in an effort to operationalize the notion of effective communication. Gibb's (1961) theory of supportive and defensive communication offers insight into specific communication behaviors that influence workplace interactions. Although Gibb's theory is ubiquitous, it has received only modest attention by empirical researchers, despite its potential for building a model of effective communication in organizations (Forward, Czech, \& Lee, 2010).

Gibb described a defensive climate as an atmosphere of mistrust and fear that typically constrains communication. A supportive climate however, engenders trust which opens communication channels. Based on his observation of group dynamics, Gibb identified six supportive and six defensive communication behaviors arranged in six, bi-polar pairs. These six pairs of elements are contrasted in terms of specific communication behaviors and styles below (Gibb, 1961).

\subsubsection{Evaluation vs. Description}

Evaluation consists of communication behaviors that employ judgmental and accusatory language. Evaluation is often marked by "you language" that places blame on the other person. Communication that is descriptive, in contrast, tends to arouse a minimum of uneasiness because the listener perceives genuine requests for information. Description is marked by the use of "I language" that places responsibility for perceptions and feelings on the message sender.

\subsubsection{Control vs. Problem Orientation}

Language which is used to control the listener evokes defensiveness. A basic interpersonal need is to control, and most social interaction with someone is trying to get them to do something, change an attitude, or to influence their behavior or activity. Problem Orientation uses language that is neither overtly persuasive nor controlling, but focuses instead on collaboration.

\subsubsection{Strategy vs. Spontaneity}

Strategy is a communication behavior that implies hidden motives and deceit. When a sender is perceived as engaging in ambiguous language with unclear motives, the message receiver will likely become defensive. Spontaneity is defined as straightforwardness, directness, and honesty. Spontaneous communication does not make up excuses but instead is consistent and transparent.

\subsubsection{Neutrality vs. Empathy}

Neutrality in speech occurs when a speaker indicates a lack of concern or welfare for the listener. People desire to be perceived as valued persons worthy of concern and affection. Empathy is thinking and feeling what you perceive another to be thinking and feeling.

\subsubsection{Superiority vs. Equality}

When a person communicates to another that they feel superior in position, power, ability, or physical characteristics, they arouse defensiveness. Equality recognizes that whatever the differences in our abilities, talents, or intellect may be, that one should treat people with respect and politeness, and as equals.

\subsubsection{Certainty vs. Provisionalism}

Certainty is defined as dogmatic, single-minded behavior; combined with unwillingness to compromise. People who communicate with certainty appear to have and know all the answers. Provisionalism reduces defensiveness by allowing for provisional attitudes, a willingness to investigate issues, and openness to new possibilities.

\subsection{Leadership}

In addition to the specific communication behaviors explicated above, leadership style also affects the supervisor-subordinate relationship and is manifest in communication behaviors. One way of conceptualizing leadership involves three behavioral clusters labeled (a) Machiavellian, (b) bureaucratic, and (c) transformational styles (Girodo, 1998). Hitt (1990) theorized that leadership style is anchored in how one exercises power and 
influence in pursuit of some objective. Based on this understanding, Girodo (1998) created a survey instrument to measure these three styles. This typology has been used in a number of contexts including leadership ethics (Hood, 2003), performance (Krimmel \& Lindenmuth, 2001), organizational culture (Mineo, 2009), decision-making (Minett, Yahman, \& Denizei, 2009), and intellectual competence (Rubin, Bartels, \& Bommer, 2002), among others.

\subsubsection{Machiavellianism}

This concept was first introduced to organizational leadership theory to describe a leader prone to use strategy and deceit in relationships (Christie \& Geis, 1970). Leaders high in Machiavellianism will do whatever it takes in order to maintain control and be successful. There is evidence to suggest that persons who exhibit Machiavellian tendencies are rewarded with initial success, expanded responsibility, and job advancement. However, there is also ample evidence demonstrating that short-term success predicated on Machiavellian tactics results in eroded relationships, increased opposition, and ineffectiveness over the long-term (Teven, McCroskey, \& Richmond, 2006).

\subsubsection{Bureaucracy}

Bureaucracy is prevalent at some level in most organizations. Bureaucracy endures because of its purported rationality, accountability, and stability (Weber, 1946). Leaders who employ a bureaucratic framework emphasize setting priorities, making orderly decisions, and communicating through established lines of authority. These leaders focus on officially mandated policies and procedures that often results in negative images of "red tape" and autocratic control (Forward, Czech, \& Allen, 2007).

\subsubsection{Transformational Leadership}

Transformational leadership has gleaned much attention over the past several years (Czech \& Forward, 2010). Burns (1978) characterized transformational leadership as a process that motivates followers by appealing to higher ideals and moral values. Transformational leaders seek to raise followers' levels of consciousness about the importance and value of high level goals and needs. Furthermore, utilization of transformational leadership has been found to increase employee satisfaction, create a supportive communication climate, and enhance individual and team performance (Charbonnier-Voirin, Akremi, \& Vandenberghe, 2010).

\subsection{Research Questions and Hypotheses}

Our research questions and hypotheses reflect two fundamental issues related to the foregoing literature review. First, we seek to empirically explore the accuracy and utility of Gibb's theory in identifying specific communication behaviors that affect workplace relationships. RQ1 (1a and 1b) will provide data to assess the connection between Gibb's specific communication behaviors and perceived supervisor effectiveness and employee relationship satisfaction. Secondly, RQ's 2 and 3 and the hypotheses link communication and leadership as it impacts supervisor-subordinate relationships and outcomes. As such, this project is a study of voice, message effects, and leadership in the workplace (Tourish \& Barge, 2010).

RQ1: What is the effect of communication on subordinate perceptions of their supervisor's effectiveness and relational satisfaction?

RQ1a: What specific communication behaviors (defensive and supportive) contribute to subordinate perceptions of their supervisor job effectiveness and relationship satisfaction?

RQ1b: What specific communication behaviors differentiate between supervisors rated high versus low in job effectiveness and high versus low in relational satisfaction?

RQ2: What is the relationship between the perceived use of defensive and supportive communication and supervisors' leadership style?

H1: Highly rated supervisors will utilize transformational leadership the most and Machiavellian leadership the least.

H2: Lowly rated supervisors will utilize Machiavellian leadership the most and transformational leadership the least.

RQ3: What is the relationship between communication behaviors and leadership style and subordinates' job satisfaction?

\section{Method}

\subsection{Sample}

The participants in this study $(\mathrm{N}=154)$ represent a convenience sample of employed adults (Dillman, 2000). The subjects ranged in age from 19 to 72 years with a mean age of $30(\mathrm{SD}=13.1)$. Fifty-eight percent $(\mathrm{n}=90)$ were female, and the sample was predominately white $(86 \%, \mathrm{n}=132)$ and Hispanic $(12 \%, \mathrm{n}=18)$. Forty-six percent 
$(n=72)$ of our subjects reported an annual income of $\$ 30,000$ or less, $23 \%(n=36)$ indicated an income between $\$ 31,000$ to $\$ 75,000$, and the remaining $15 \%(n=23)$ reported income greater than $\$ 75,000$.

Additionally, a plurality of respondents $(38.3 \%, \mathrm{n}=59)$ worked for their current supervisor for less than one year. Another thirty-nine (25.3\%) have worked for their current supervisor one to four years, and the remainder (21.4\%, $\mathrm{n}=33$ ) have worked for the same supervisor for more than four years. Lastly, $42 \%(\mathrm{n}=58)$ of the supervisors rated were female, $58 \%(n=73)$ were male, and the remainder neglected to indicate the sex of the supervisor.

\subsection{Procedures}

Subsequent to IRB approval and a pilot test of the instrument, undergraduate research assistants contacted potential respondents through e-mail and social networking sites such as Facebook, Linked-in, and Twitter. Those who were employed full-time and willing to complete the survey were sent a link to Survey Monkey, along with instructions on how to submit the completed instrument. The 80-question survey consisted primarily of Likert-type questions utilizing a 5 point metric scaled from 1 (almost never) to 5 (almost always). The two items related to overall supervisor effectiveness and relationship satisfaction were measured using a 10-point metric scaled from 1 (not at all) to 10 (extremely).

\subsection{Instrumentation}

We assessed the internal consistency and dimensionality of each summated variable in several ways. First we examined Cronbach's alpha as a measure of reliability for each variable. Warner (2008) has suggested that a coefficient alpha of .70 is a generally accepted standard for social science research. All of the variables in this study met or exceeded the .70 standard, except one. Bureaucracy achieved an alpha of .68 and, with due caution, has been retained in the data set (see Keyton, 2001 for a fuller discussion of this decision rationale). Descriptive statistics for all of the summated variables including means, standard deviations, and Cronbach's alphas are reported in Table 1.

Table 1. Descriptive Statistics

\begin{tabular}{|c|c|c|c|c|}
\hline Variable & $M$ & $S D$ & $a$ & \# of Items \\
\hline \multicolumn{5}{|l|}{ Supportive Communication } \\
\hline Description & 3.3 & .80 & .83 & 3 \\
\hline Problem Orientation & 3.6 & .97 & .85 & 3 \\
\hline Spontaneity & 3.5 & 1.0 & .88 & 3 \\
\hline Empathy & 3.7 & .92 & .84 & 3 \\
\hline Equality & 3.2 & 1.0 & .80 & 3 \\
\hline Provisionalism & 3.5 & .95 & .80 & 3 \\
\hline \multicolumn{5}{|l|}{ Defensive Communication } \\
\hline Evaluation & 2.5 & 1.0 & .83 & 3 \\
\hline Control & 3.0 & .94 & .72 & 3 \\
\hline Strategy & 2.5 & 1.1 & .88 & 3 \\
\hline Neutrality & 2.5 & .79 & .70 & 3 \\
\hline Superiority & 2.9 & .93 & .73 & 3 \\
\hline Certainty & 2.6 & 1.1 & .87 & 3 \\
\hline \multicolumn{5}{|l|}{ Leadership } \\
\hline Machiavellian & 2.6 & .97 & .85 & 5 \\
\hline Bureaucratic & 3.2 & .73 & .68 & 5 \\
\hline Transformational & 3.3 & .91 & .85 & 5 \\
\hline Employee Job Satisfaction & 3.5 & .66 & .90 & 18 \\
\hline Supervisor Job Effectiveness & 6.8 & 2.5 & -- & 1 \\
\hline Relationship Satisfaction & 6.6 & 2.9 & -- & 1 \\
\hline
\end{tabular}

Next we examined the relationships between variables to assess the possibility of multicollinearity. The simplest means of identifying collinearity is through an examination of the correlation matrix. Although the exact threshold is open to debate, estimates of problematic correlations vary among researchers and range from the mid to high .70's on the low end (Meyers, Gamst, \& Guarino, 2013), to anything above .80 (Allison, 1999), all the way to .90 on the upper end (Hair, Anderson, Tatham, \& Black, 1992). Since there were a few correlations in 
the upper .70 's to .81 , we explored the tolerance and VIF collinearity statistics. The tolerance values were all substantially above .10 and the VIF numbers were all substantially lower than 10 , indicating no overarching concerns relating to multicollinearity (Leach, Barrett, \& Morgan, 2005). The correlation matrix is presented in Table 2.

Table 2. Correlation matrix $(\mathrm{N}=154)$

\begin{tabular}{|c|c|c|c|c|c|c|c|c|c|c|c|c|c|c|c|c|c|c|}
\hline Variable & 1 & 2 & 3 & 4 & 5 & 6 & 7 & 8 & 9 & 10 & 11 & 12 & 13 & 14 & 15 & 16 & 17 & 18 \\
\hline 1. EV & -- & & & & & & & & & & & & & & & & & \\
\hline 2. $\mathrm{CO}$ & .66 & -- & & & & & & & & & & & & & & & & \\
\hline 3. ST & .69 & .68 & -- & & & & & & & & & & & & & & & \\
\hline 4. NV & .44 & .37 & .58 & -- & & & & & & & & & & & & & & \\
\hline 5. SU & .73 & .69 & .71 & .38 & -- & & & & & & & & & & & & & \\
\hline 6. CE & .77 & .68 & .81 & .54 & .71 & -- & & & & & & & & & & & & \\
\hline 7. $\mathrm{DE}$ & -.70 & -.64 & -.81 & -.50 & -.69 & -.74 & -- & & & & & & & & & & & \\
\hline 8. PO & -.57 & -.57 & -.70 & -.58 & -.60 & -.71 & .68 & -- & & & & & & & & & & \\
\hline 9. SP & -.66 & -.68 & -.84 & -.59 & -.71 & -.76 & .78 & -.79 & -- & & & & & & & & & \\
\hline 10. EM & -.69 & -.64 & -.74 & -.68 & -.60 & -.74 & .73 & .71 & .79 & -- & & & & & & & & \\
\hline 11. EQ & -.72 & -.73 & .77 & -.53 & -.76 & -.77 & .76 & .71 & .80 & .76 & -- & & & & & & & \\
\hline 12. PR & -.68 & -.69 & -.71 & -.55 & -.66 & -.72 & .69 & .76 & .81 & .78 & .73 & -- & & & & & & \\
\hline 13. MA & .65 & .60 & .77 & .56 & .70 & .72 & -.71 & -.55 & -.75 & -.65 & -.72 & -.65 & -- & & & & & \\
\hline 14. $\mathrm{BU}$ & $.15^{\mathrm{ns}}$ & .23 & $.14^{\mathrm{ns}}$ & $.08^{\mathrm{ns}}$ & $.20 *$ & $.12^{\mathrm{ns}}$ & $-.05^{\mathrm{ns}}$ & $-.10^{\mathrm{ns}}$ & $-.11^{\mathrm{ns}}$ & $-.09^{\mathrm{ns}}$ & $-.21 *$ & $-.18 *$ & .26 & -- & & & & \\
\hline 15. TR & -.61 & -.53 & -.64 & -.63 & -.50 & -.69 & .70 & .71 & .71 & .74 & .68 & .70 & -.49 & $.13^{\mathrm{ns}}$ & -- & & & \\
\hline 16. JS & -.61 & -.56 & -.68 & -.60 & -.52 & -.68 & .63 & .68 & .74 & .72 & .66 & .68 & -.61 & $-.07^{\mathrm{ns}}$ & .65 & -- & & \\
\hline 17. JE & -.62 & -.54 & -.73 & -.62 & -.56 & -.73 & .73 & .70 & .74 & .71 & .62 & .67 & -.60 & $.02^{\mathrm{ns}}$ & .67 & .74 & -- & \\
\hline 18. RS & -.77 & .66 & -.78 & -.63 & -.69 & -.75 & .80 & .72 & .81 & .83 & .80 & .76 & -.70 & $-.19 *$ & .71 & .75 & .73 & -- \\
\hline
\end{tabular}

Note. $\mathrm{DE}=$ description; $\mathrm{PO}=$ problem orientation; $\mathrm{PR}=$ provisionalism; $\mathrm{EM}=$ empathy; $\mathrm{EQ}=$ equality; $\mathrm{SP}=$ spontaneity; $\mathrm{SU}=$ superiority; $\mathrm{EV}=$ =valuation; $\mathrm{CE}=$ certainty; $\mathrm{NE}=$ neutrality; $\mathrm{CO}=$ control; $\mathrm{ST}=$ strategy; JE=supervisor effectiveness; RS=relationship satisfaction; MA=Machiavellianism; BU=bureaucracy; TR=transformational; JS=employee job satisfaction.

\subsubsection{Communication Behaviors}

Gibb (1961) first theorized six characteristics of a supportive communication climate and six factors of a defensive communication climate. The communication inventory developed by Costigan and Schmeidler (1984) operationalized these twelve factors to assess communication within organizational settings. The original wording of each question was altered to reflect the supervisor/subordinate relationship. Each category of defensive and supportive communication was measured with three questions (see Appendix).

\subsubsection{Leadership}

Leadership was assessed using the Leadership Style Questionnaire, developed by Girodo (1998). This instrument conceptualizes leadership as consisting of three styles (Machiavellian, bureaucratic, and transformational) defined primarily in terms of interpersonal orientation toward others in the use of influence and power.

A high score on Machiavellianism suggests a willingness to use coercion or manipulation in pursuit of a desired end. A representative question includes: "My manager uses power, rather than persuasion, to control events and people." A bureaucratic style focuses on officially mandated policies and procedures and the enforcement of rules (Forward, 2001). Bureaucracy was assessed with questions like: "My manager utilizes the organizational hierarchy with clear lines of authority in order to be effective." Lastly, a transformational style of leadership engages followers in behaviors that are supportive, and lead to individual growth and mutual accountability (Dvir, Eden, Avolio, \& Shamir, 2002). This was measured by questions like: "My manager treats people in terms of their potential when determining their effectiveness."

\subsubsection{Job Satisfaction}

Job satisfaction is the affective response to one's organizational role and the demands associated with it. This variable was measured using Spector's (1997) Job Satisfaction Scale and was assessed with questions like: "I feel a sense of pride in doing my job."

\subsubsection{Effectiveness and Relationship Satisfaction}

Two questions were utilized to evaluate supervisor effectiveness and employee relationship satisfaction with that supervisor. Both questions provided a 10 point Likert-type scale in order to maximize variance. ${ }^{1}$ The first question asked employees to rate how effective their manager is in doing his/her job. The second question asked employees to indicate how satisfied they are in their interpersonal relationship with their manager. 


\subsubsection{Demographics}

The final section of the survey collected data about the respondents. Respondents reported their age, sex, and ethnicity, as well as their income, how long they have worked for their current supervisor and their supervisors' sex. We collected this information in order to accurately describe our sample as well as explore possible predictive contributions to our statistical analyses based on demographics.

\section{Results}

\subsection{Supervisor Communication Behavior}

We answered research question 1a by using multiple regression to assess the relationship between communication and employee perceptions of supervisor effectiveness and relationship satisfaction. The first model used supervisor effectiveness as the dependent variable with supportive and defensive communication and demographics in the independent variable set. The regression resulted in an adjusted $\mathrm{R}^{2}=.67, \mathrm{~F}(5,122)=51.83$, $\mathrm{p}<.001$ (Table 3).

Table 3. Stepwise Regression of Supervisor Effectiveness

\begin{tabular}{lllll}
\hline Variable & $R^{2}$ & $R^{2}$ Cha & $B$ & $t$ \\
\hline Spontaneity & .56 & .56 & .65 & $2.61^{* *}$ \\
Certainty & .62 & .06 & -.77 & $-3.67^{* * *}$ \\
Descriptive & .65 & .03 & .92 & $3.57^{* *}$ \\
Neutrality & .67 & .02 & -.64 & $-2.89^{* *}$ \\
Equality & .68 & .01 & -.53 & $-2.21^{*}$ \\
\hline
\end{tabular}

Note. $\mathrm{N}=154 ; \mathrm{SE}=1.47$; Adjusted $\mathrm{R}^{2}=.67 ; \mathrm{F}=51.83 ;$ Constant $=6.79 .{ }^{*} \mathrm{p}<.05 ; * * \mathrm{p}<.01 ; * * * \mathrm{p}<.001$

The second regression model utilized employee-supervisor relationship satisfaction as the dependent variable with the same supportive and defensive communication behaviors and demographics in the independent variable set. This procedure resulted in an adjusted $\mathrm{R}^{2}=.79, \mathrm{~F}(4,123)=123.51, \mathrm{p}<.001$ (Table 4).

Table 4. Stepwise Regression of Supervisor-Subordinate Relationship Satisfaction

\begin{tabular}{lllll}
\hline Variable & $R^{2}$ & $R^{2}$ Cha & $B$ & $t$ \\
\hline Empathy & .70 & .70 & 1.18 & $5.32^{* * *}$ \\
Description & .77 & .07 & .87 & $3.81^{* * *}$ \\
Equality & .79 & .02 & .58 & $2.77^{* *}$ \\
Evaluation & .80 & .01 & -.40 & $-2.17^{*}$ \\
\hline
\end{tabular}

Note. $\mathrm{N}=154 ; \mathrm{SE}=1.34 ;$ Adjusted $\mathrm{R}^{2}=.79 ; \mathrm{F}=123.51, \mathrm{p}<.001$; Constant $=-1.34 .{ }^{*} \mathrm{p}<.05 ; * * \mathrm{p}<.01 ; * * * \mathrm{p}<.001$

We answered question $1 \mathrm{~b}$ with a pair of t-tests comparing supervisors evaluated as high versus low in effectiveness and high versus low in employee-supervisor relationship satisfaction. Supervisor effectiveness ratings were operationalized as one-half standard deviation or more from the mean in either direction. ${ }^{2}$ Managers who utilized supportive communication were seen as more effective in their jobs (Table 5).

Table 5. t-test Comparison of High vs. Low Effectiveness in Communication Behaviors

\begin{tabular}{lccccc}
\hline & \multicolumn{4}{c}{ Higher Effectiveness $^{\mathrm{a}}$} & \multicolumn{3}{c}{ Lower Effectiveness $^{\mathrm{b}}$} & \\
Variable & $M$ & $S D$ & $M$ & $S D$ & $t$ \\
\hline Supportive Communication & & & & & \\
$\quad$ Description & 3.82 & .66 & 2.31 & .56 & -11.64 \\
$\quad$ Problem Orientation & 4.11 & .65 & 2.56 & .83 & -10.37 \\
$\quad$ Provisionalism & 4.03 & .66 & 2.54 & .84 & -9.83 \\
$\quad$ Empathy & 4.19 & .53 & 2.68 & .91 & -9.28 \\
$\quad$ Equality & 3.70 & .83 & 2.18 & .78 & -9.02 \\
$\quad$ Spontaneity & 4.11 & .70 & 2.34 & .84 & -11.17 \\
Defensive Communication & & & & & \\
$\quad$ Superiority & 2.40 & .76 & 3.72 & .79 & 8.21 \\
$\quad$ Evaluation & 1.92 & .81 & 3.42 & .86 & 8.63 \\
$\quad$ Certainty & 2.02 & .72 & 3.88 & .81 & 11.82 \\
$\quad$ Neutrality & 2.06 & .57 & 3.11 & .73 & 7.99 \\
$\quad$ Control & 2.56 & .85 & 3.83 & .65 & 7.88 \\
$\quad$ Strategy & 1.71 & .71 & 3.77 & .84 & 13.12 \\
\hline
\end{tabular}

Note. All differences between means are significant at $p<.001 . \quad{ }^{a} n=60 ;{ }^{b} n=38$. 
All of the predictor variables were significant at p. $<.001, \mathrm{df}=96$. The effect size $d$ is greater than 1.0 for all twelve communication behaviors, indicating a much larger than typical effect (Cohen, 1988).

We used a second t-test to determine how satisfied respondents were with their employee-supervisor relationship. Results indicated that the two groups were significantly different on all variables with $\mathrm{p}<.001$, $\mathrm{df}=104$. Respondents were more satisfied in their personal relationship if they reported their manager as utilizing supportive communication behaviors. Again, the effect size $d$ was greater than 1.0 for all twelve behaviors indicating a much larger than typical result (Cohen, 1988). These results are summarized in Table 6.

Table 6. t-test Comparison of High vs. Low Relational Satisfaction

\begin{tabular}{llcccc}
\hline & \multicolumn{3}{l}{ Higher Satisfaction $^{\mathrm{a}}$} & \multicolumn{3}{c}{ Lower Satisfaction $^{\mathrm{b}}$} \\
Variable & $M$ & $S D$ & $M$ & $S D$ & $t$ \\
\hline Supportive Communication & & & & & \\
$\quad$ Description & 3.87 & .60 & 2.41 & .65 & -11.87 \\
$\quad$ Problem Orientation & 4.12 & .66 & 2.70 & .92 & -8.76 \\
$\quad$ Provisionalism & 4.11 & .53 & 2.58 & .83 & -10.70 \\
Empathy & 4.24 & .48 & 2.70 & .87 & -10.68 \\
Equality & 3.92 & .62 & 2.15 & .77 & -13.11 \\
$\quad$ Spontaneity & 4.12 & .64 & 2.45 & .89 & -10.91 \\
Defensive Communication & & & & & \\
$\quad$ Superiority & 2.31 & .66 & 3.68 & .84 & 8.94 \\
Evaluation & 1.82 & .65 & 3.45 & .93 & 10.07 \\
$\quad$ Certainty & 1.96 & .74 & 3.71 & .95 & 10.11 \\
$\quad$ Neutrality & 2.03 & .51 & 2.99 & .81 & 6.96 \\
Control & 2.41 & .81 & 3.85 & .63 & 9.84 \\
Strategy & 1.69 & .74 & 3.64 & 1.03 & 10.70 \\
\hline
\end{tabular}

Note. All differences between means are significant at $\mathrm{p}<.001 .{ }^{\mathrm{a}} \mathrm{n}=62 ;{ }^{\mathrm{b}} \mathrm{n}=44$.

\subsection{Supervisor Leadership}

Research question 2 utilized three stepwise multiple regression models to assess the relationship between the perceived use of defensive and supportive communication behaviors and the manger's leadership style. In turn, each leadership style (Machiavellian, bureaucratic, and transformational) served as the dependent variable while defensive and supportive communication and demographics served as the independent variable set (Table 7).

Table 7. Stepwise Regression of Leadership Types on Communication Behaviors

\begin{tabular}{|c|c|c|c|c|}
\hline Variable & $R^{2}$ & $R^{2} C h a$ & $B$ & $t$ \\
\hline \multicolumn{5}{|l|}{ Machiavellian Style } \\
\hline Strategy & .63 & .63 & .40 & $5.22 * * *$ \\
\hline Superiority & .68 & .05 & .30 & $3.90 * * *$ \\
\hline Spontaneity & .70 & .02 & -.43 & $-4.13 * * *$ \\
\hline Provisionalism & .72 & .02 & .20 & $2.25^{*}$ \\
\hline Problem Orientation & .73 & .01 & .17 & $1.99 *$ \\
\hline \multicolumn{5}{|c|}{ Note. $\quad \mathrm{N}=111 ; \quad \mathrm{SE}=.53 ; \quad$ Adjusted $\mathrm{R}^{2}=.72 ; \quad$ constant $=1.07$} \\
\hline \multicolumn{5}{|c|}{ Bureaucratic Style } \\
\hline Control & .12 & .12 & .27 & $3.84^{* * * *}$ \\
\hline Note. $\quad \mathrm{N}=111 ; \mathrm{SE}=.70$ & ted $\mathrm{R}$ & $\mathrm{nt}=2.4$ & & \\
\hline \multicolumn{5}{|c|}{ Transformational Style } \\
\hline Empathy & .57 & .57 & .44 & $4.50^{* * *}$ \\
\hline Problem Orientation & .61 & .04 & .21 & $2.65^{* *}$ \\
\hline Description & .63 & .02 & .21 & $2.32 *$ \\
\hline
\end{tabular}

Note. $\mathrm{N}=111 ; \quad \mathrm{SE}=.57 ; \quad$ Adjusted $\mathrm{R}^{2}=.62 ;$ constant $=1.01$

$* \mathrm{p}<.05 ; * * \mathrm{p}<.01 ; * * * \mathrm{p}<.001$ 
This first model (Machiavellian) resulted in an adjusted $\mathrm{R}^{2}=.72, \mathrm{~F}(5,107)=57.3, \mathrm{p}<.001$ and is summarized in Table 7. The next model (bureaucratic) resulted in an adjusted $\mathrm{R}^{2}=.11, \mathrm{~F}(1,112)=14.76, \mathrm{p}<.001$. The third stepwise regression model used transformational leadership as the dependent variable resulting in an adjusted $\mathrm{R}^{2}$ $=.62, \mathrm{~F}(3,109)=61.71, \mathrm{p}<.001$. The specific results for each procedure are listed in Table 7 .

In order to answer our two hypotheses, we explored the relationship between leadership styles and employee perceptions of manager effectiveness and relationship satisfaction with two t-tests. Although there are virtually no differences between managers in the use of bureaucratic leadership, supervisors who are perceived as more effective and higher in relationship satisfaction score higher in transformational leadership and lower in Machiavellian leadership than their less positively evaluated peers. Thus both of our directional hypotheses were supported. These relationships and findings are presented in Table 8.

Table 8. t-test Comparison of Leadership Styles

\begin{tabular}{|c|c|c|c|c|c|c|c|c|c|}
\hline \multirow{2}{*}{$\begin{array}{l}\text { Supervisor } \\
\text { Rating }\end{array}$} & \multicolumn{3}{|c|}{ Machiavellianism } & \multicolumn{3}{|c|}{ Bureaucracy } & \multicolumn{3}{|c|}{ Transformational } \\
\hline & $M$ & $S D$ & $t$ & $M$ & $S D$ & $t$ & $M$ & $S D$ & $t$ \\
\hline \multicolumn{10}{|l|}{ Effectiveness } \\
\hline Higher $^{\mathrm{a}}$ & 2.11 & .72 & $9.33^{* * *}$ & 3.20 & .68 & .03 & 3.69 & .73 & $-9.08 * * *$ \\
\hline Lower ${ }^{\mathrm{b}}$ & 3.48 & .69 & & 3.21 & .78 & & 2.31 & .74 & \\
\hline \multicolumn{10}{|c|}{ Relational Satisfaction } \\
\hline Higher $^{\mathrm{c}}$ & 2.11 & .68 & $9.10 * * *$ & 3.10 & .81 & $2.30 *$ & 3.75 & .58 & $-8.32 * * *$ \\
\hline Lower $^{\mathrm{d}}$ & 3.50 & .89 & & 3.44 & .68 & & 2.48 & .89 & \\
\hline
\end{tabular}

Note. ${ }^{a} \mathrm{n}=60 ;{ }^{b} \mathrm{n}=38 ;{ }^{\mathrm{c}} \mathrm{n}=62 ;{ }^{\mathrm{d}} \mathrm{n}=44 . \quad * \mathrm{p}<.05 ; * * * \mathrm{p}<.001$.

\subsection{Employee Job Satisfaction}

Finally, research question 3 assessed the relationship between leadership style and communication behaviors on employee job satisfaction. Again, we used a multiple regression procedure to answer this question resulting in an adjusted $\mathrm{R}^{2}=.60, \mathrm{~F}(4,108)=54.93, \mathrm{p}<.001$. Overall, workers were more satisfied with their job if their supervisor used supportive communication and a transformational leadership style, while simultaneously avoiding defensive communication behaviors (Table 9).

Table 9. Stepwise Regression of Employee Job Satisfaction

\begin{tabular}{lllll}
\hline Variable & $R^{2}$ & $R^{2} C h a$ & $B$ & $t$ \\
\hline Spontaneity & .55 & .55 & .24 & $3.83^{* * *}$ \\
Empathy & .59 & .04 & .18 & $2.37^{*}$ \\
Transformational & .61 & .02 & .15 & $2.25^{*}$ \\
\hline
\end{tabular}

Note. $\mathrm{N}=154 ; \mathrm{SE}=.43 ;$ Adjusted $\mathrm{R}^{2}=.60 ; \mathrm{F}=61.87, \mathrm{p}<.001 ;$ Constant $=1.41$.

$* \mathrm{p}<.05 ; * * * \mathrm{p}<.001$

\section{Discussion}

\subsection{Supervisor Effectiveness \& Relationship Satisfaction}

Perceptions of supervisor job effectiveness were predicted by the supportive behaviors of spontaneity and description and the avoidance of certainty and neutrality. Employees seek a clear description of their role and the expectations associated with it. Snow (2002) found that productivity was higher and employees were more task effective and satisfied with their jobs when workers had a clear idea of role expectations, their contribution to organizational mission and policies, and clear lines of authority. Furthermore, descriptive communication is indicative of a higher level of communication competence that appears critical to effective organizational behavior (Madlock, 2008).

However, contrary to Gibb's theory, our results show a negative relationship between equality and subordinates perceptions of superior effectiveness. Path Goal Theory (House, 1971) may help explain this counterintuitive finding. Research indicates that leaders who initiate structure for subordinates are generally rated higher, and this could be the reason for some modest inequality to contribute to perceptions of supervisor effectiveness.

In addition, relationship satisfaction was predicted by empathy and description. Empathy has a clear connection with relationship satisfaction and concurs with research that highlights the importance of emotional support (Albrecht \& Adelman, 1987). Description was the second supportive communication behavior that contributed to relational satisfaction, once again indicating employees' desire for clear communication, job roles, and duties. 
Since there is usually a clear power and status differential between supervisor and employee, the intentional use of descriptive communication behaviors may help an employee feel more comfortable with the relationship (Snow, 2002).

\subsection{Supervisor Comparisons}

Our hypotheses looked at the differences between supervisors that were highly rated versus supervisors who were rated lower in terms of both perceived effectiveness and relational satisfaction. Employees rated their supervisors more highly, without exception, if they utilized supportive communication behaviors and refrained from defensive communication behaviors in interactions with employees. On the contrary, employees rated supervisors who used defensive communication behaviors, and refrained from using supportive communication, as much lower overall. Supportive communication relates positively to employees perceptions of their supervisors' competence as well as leading to more motivated and trusting employees (Jo \& Shim, 2005).

\subsection{Leadership Styles}

\subsubsection{Machiavellian Style}

Machiavellianism was highly related to 5 communication behaviors including strategy, and its inverse opposite, spontaneity. Strategy is the essence of the Machiavellian leader and was the strongest predictor of this leadership style. A Machiavellian leader engages in communication that involves manipulation, deceit, withholding or distorting information, as well as outright lies in order to achieve what they want (Teven, McCrosky, \& Richmond, 2006). In addition, our data reveals an inverse relationship with spontaneity indicating that Machiavellian leaders engage in manipulation rather than transparent or honest communication (Walter, Anderson, \& Martin, 2005).

Machiavellianism was also predicted by the defensive communication behavior of superiority. Superiority echoes the Machiavellian's need to control and have power over others. As such, Machiavellianism can be seen as social competition concerned with gaining the upper hand at all costs (Barber, 1994).

The final two predictors of Machiavellianism were somewhat of a surprise since both are supportive communication behaviors with a positive relationship to Machiavellianism. The behaviors of provisionalism and problem orientation have not typically been associated with Machiavellian leaders. However, the Machiavellian leader is somewhat complex and will engage in "whatever it takes" to achieve their goal, including mimicking supportive behaviors (Walter, Anderson, \& Martin, 2005). Machiavellian leaders may appear open to the opinions of others (problem-orientation) although they communicate in order to uncover information that can be used to manipulate others (Gable \& Dangello, 1994).

\subsubsection{Bureaucratic Style}

Bureaucracy was modestly predicted by the defensive communication behavior of control. As an authority figure, the bureaucratic leader exercises power by controlling rules, policies, and decision-making criteria. Weber (1946, p. 30) characterized bureaucracy as a "closed system driven by rational-legal authority, with a reliance on rules, clearly established hierarchy, and centralized power." Even if supervisors do not personally possess all that much control, they typically communicate the decisions, rules, and procedures mandated by upper management to other employees. The impersonal appeal to rules and regulations can frustrate the most patient person and lead employees to conclude that the "bureaucracy" is more rational, controlling, and authoritative than it actually is or needs to be.

\subsubsection{Transformational Style}

Transformational leadership was predicted by several supportive communication behaviors, including empathy, problem orientation, and description. Similarly, these same supportive communication behaviors were linked to employees' perceptions of highly effective supervisors and high relationship satisfaction. The first predictor, empathy, is indicative of the main philosophical drive behind transformational leadership. Transformational leaders are concerned with the well-being and development of their followers and facilitate motivation by highlighting relevant beliefs and values (Northouse, 2001). In addition, research has also recognized a significant link between emotional support and empathy as an element of transformational leadership (Lussiez, 2010).

The next predictor of transformational leadership was problem orientation. Problem orientation is conveyed through language that communicates a desire to collaborate and engage in mutual problem solving. Transformational leaders specifically motivate followers through a process of empowerment and actualization. Spreitzer, Kizilos, and Nanson, (1997) note that empowerment is a concomitant of participative management and effective leadership. Once again, our study confirms the assertion that employees are more satisfied and productive when they are included in the overall operation and decisions of an organization (Kim, 2002). 
The final predictor of transformational leadership was the supportive communication behavior of description. Description is clear, non-evaluative communication that does not show judgment. Transformational leaders foster an open climate where members experience encouragement and vision is communicated to followers with their values and concerns in mind (Kanungo \& Mendonca, 1996). Research suggests that employees desire role clarity, procedural fairness, and a non-judgmental environment. Transformational leadership, by definition, evokes all three of these predictive, supportive communication behaviors.

\subsection{Job Satisfaction}

There were four predictors of employee job satisfaction. The first two included the supportive communication behaviors of spontaneity and problem orientation. As discussed throughout this paper, employees reported higher satisfaction when supervisors were honest and clear in their intentions and involved employees in collaboration and decision-making in the organization. The third predictor of job satisfaction was the defensive behavior of evaluation.

Unsurprisingly, evaluation had an inverse relationship with job satisfaction, suggesting that employees do not like language perceived as a "put-down." Rather, they prefer the supportive communication behavior of description, which is more factual and less judgmental, and has been a consistent predictor of several positive outcomes in this study.

Lastly, income also revealed an inverse relationship with employee job satisfaction. While this may seem surprising at first, there is little empirical evidence to suggest that income plays a significant role in employees' job satisfaction. Despite popular assumptions to the contrary, Judge, Piccolo, Padsakoff, Shaw and Rich (2010) have noted that research has consistently shown that pay level is only marginally related to job satisfaction. Money alone cannot compensate for a negative communication climate, feckless leadership, or enervating relationships at work.

\subsection{Limitations}

We wish to acknowledge three issues which we believe to be relevant in interpreting the findings presented in this paper. First we have relied on a convenience sample of moderate size $(\mathrm{N}=154)$. All of the respondents live and work in southern California and younger workers are over-represented, reflecting our use of student assistants to recruit participants through social media. Greater diversity in both age and geographic location would enhance the generalizability of our findings.

Secondly, all of the caveats concerning self-report survey data apply. It is an a priori, fixed format modality which assumes thoughtful and accurate responses from participants. Nonetheless, as Howard (1994, p. 403) notes, "when employed within a sensible design, self-reports often represent a valuable and valid measurement strategy." Since employees in our research were asked to reflect their own perceptions of their supervisor's behaviors, we have reason to believe that an acceptable threshold has been achieved here.

Lastly, the instrument used to assess the communication climate behaviors (Costigan \& Schmeidler, 1984) has had little previous empirical research use. Gibb himself never created an assessment tool operationalizing his concepts of supportive and defensive communication. In addition, more than 20 years passed before Costigan and Schmeidler (1984) created and made available their measurement instrument which has been used more often in professional, rather than academic settings. For a full discussion of potential issues with the instrument, see Forward, Czech, and Lee (2011).

\subsection{Conclusion and Implications}

One purpose for this study was to empirically assess Gibb's model of supportive and defensive communication in a variety of employment contexts. Although the supportive-defensive communication construct is ubiquitous in interpersonal, small group, and organizational communication texts, there has been little empirical validation of the theory despite its iconic status (Forward, Czech, \& Lee, 2011). This is the result of a 23 -year gap between the publication of Gibb's 1961 article and the broad availability of an assessment instrument as well as the practitioner emphasis in early organizational communication scholarship (Redding, 1985). Nonetheless, our previous research has shown significant utility with both the theoretical notion of supportive and defensive communication behaviors and the instrument created to assess those behaviors (Czech \& Forward, 2010). Since this previous research was limited to the context of the chair-faculty relationship in higher education, the current study is an effort to expand our research across different types of supervisor-subordinate relationships. As a result we now have data to suggest the following. 


\subsection{Implications}

The first implication involves the utility of Gibb's theory as a valid construct for assessing communication and its effects. Gibb offers a direct, concrete model of specific communication behaviors that give substance to the notions of supportive and defensive communication. This research evaluated the relative importance of certain behaviors on desirable outcomes like relationship satisfaction, perceived leader effectiveness, and employee job satisfaction. Investigating Gibb's model at this level of granularity reveals, for example, that 4 of the 6 supportive behaviors and 3 of the 6 defensive behaviors are statistically significant predictors of the positive outcomes noted above. Likewise, 4 of the 6 supportive behaviors and 3 of the 6 defensive behaviors predict perceptions of leadership style. In addition, certain behaviors like the inverse relationship between equality and perceived effectiveness and the contribution of problem orientation to higher scores on Machiavellianism are counter-intuitive and would not be predicted by the theory. Therefore, our study begins to pave the way for continued empirical research in utilizing Gibb's theory. Certainly these findings provide some reassurance that Gibbs' status in the literature is warranted, while simultaneously highlighting the need for critical evaluation of his model.

A second significant implication that emerges from these data is support for the discursive nature of leadership. "If leadership theory and research is to adequately account for the messiness and complexity of organizational life," argues Barge (2008, p. 2), interaction and discourse between individuals must be taken seriously. As such, communication is not one element or variable among many others that can be used to gain insight into leadership, but is the essence of leadership itself. The real work of a supervisor is not to manage a department or even organizational functions but to manage conversations and meaning. Leadership is a communication phenomenon as leaders use language, stories, metaphors, narrative, and rituals to discuss the past, the present, and the future in which they reveal their visions and goals (Hackman \& Johnson, 2009). Patterns of communication shape the perceptions subordinate's have of a leader, reveal taken-for-granted assumptions about the workplace, and what is expected, acceptable, and possible in terms of supervisor - subordinate relationships.

The last implication concerns the persistent patterns of interaction instantiated in communication behaviors. According to Tourish and Barge (2010, p. 323), "the study of leadership inevitably becomes an exploration of leader and message effects." This research reveals relationships between certain communication behaviors and leadership styles, perceptions of effectiveness and relationship satisfaction, and employee job satisfaction which are powerful, pervasive, and demonstrable. Although all twelve communication behaviors are statistically significant predictors of at least one of the leadership or outcome variables, they are not all equally important. Description, empathy, and spontaneity are the most robust and frequent statistically significant predictors of perceived leader effectiveness, relationship satisfaction, and employee job satisfaction. Managers' who have learned the utility of being pro-active in managing workplace meaning and relationships, should systematically and anonymously solicit feedback from subordinates in an effort to gauge the dominant perceptions of their communication as it pertains to their leadership and workplace relationships.

\section{References}

Albrecht, W. J., \& Adelman, M. D. (1987). Communicating social support. Newbury Park: Sage.

Allison, P. D. (1999). Multiple regression: A primer. Thousand Oaks: Pine Forge Press.

Barber, N. (1994). Machiavellianism and altruism: Effects of relatedness of target person on Machiavellianism and helping attitudes. Psychological Reports, 75, 403-422.

Barge, J. K. (2008, November). Psychological and discursive leadership approaches to context. Paper presented at the meeting of the National Communication Association, Boston, MA.

Becker, J.A.H., \& O'Hair, H.D. (2007). Machiavellians' motives in organizational citizenship behavior. Journal of Applied Communication Research, 35(3), 246-267. http://dx.doi.org/10.1080/00909880701434232

Bernard, H. R. (2000). Social science research methods: Qualitative and quantitative approaches. Thousand Oaks: Sage.

Burns, J. (1978). Leadership. New York: Harper \& Row.

Charbonnier-Voirin, A., Akremi, A., \& Vandenberghe, C. (2010). A multivariate model of transformational leadership and adaptive performance and the moderating role of climate for innovation. Group \& Organization Management, 35(6), 699-726. http://dx.doi.org/10.1177/1059601110390833

Christie, R., \& Geis, F. L. (1970). Studies in Machiavellianism. New York: Academic Press. 
Cohen, J. (1988). Statistical power and analysis for the behavioral sciences $\left(2^{\text {nd }}\right.$ ed.). Hillsdale, NJ: Lawrence Erlbaum Associates, Inc.

Costigan, J. L., \& Schmeidler, M. A. (1984). Exploring supportive and defensive communication climates. In J.W. Pfeiffer \& L.D. Goodstein (Eds.), The 1984 handbook for group facilitators (pp. 112-114). San Diego, CA: University Associates.

Czech, K., \& Forward, G. L. (2010). Leader communication: Faculty perceptions of the department chair. Communication Quarterly, 58(4), 431-457. http://dx.doi.org/10.1080/01463373.2010.525158

Daniels, T. D., Spiker, B. K., \& Papa, M. J. (1997). Perspectives on organizational communication (4 ${ }^{\text {th }}$ ed.). Madison, WI: Brown \& Benchmark.

Dillman, D. (2000). Mail and internet surveys: The tailored design method. New York: Wiley.

Dvir, T., Eden, D., Avolio, B. J., \& Shamir, B. (2002). Impact of transformational leadership on follower development and performance: A field experiment. Academy of Management Journal, 45(4), 735-744. http://dx.doi.org/10.2307/3069307

Forward, G. L. (2001). Servant or CEO? A metaphor analysis of leadership in a nonprofit context. The Atlantic Journal of Communication, 9(2), 145-165. http://dx.doi.org/10.1080/15456870109367406

Forward, G. L., Czech, K., \& Allen, P. A. (2007). Leadership, communication and religiosity in higher education administration: Distinctions that make a difference. Journal of Communication and Religion, 30(1), 153-185.

Forward, G. L., Czech, K., \& Lee, C. M. (2011). Assessing Gibb's supportive and defensive communication climate: An examination of measurement and construct validity. Communication Research Reports, 28(1), 1-15. http://dx.doi.org/10.1080/08824096.2011.541360

Gable, M., \& Dangello, F. (1994). Locus of control, Machiavellianism, and managerial job performance. Journal of Psychology, 128, 599-608.

Gibb, J. (1961). Defensive communication. The Journal of Communication, 11,141-148.

Gibbons, J. M. (2010). I can't get no...job satisfaction, that is (Research Report No. R-1459-09-RR). Retreived from The Conference Board website: http://www.conference-board.org/publications.

Girodo, M. (1998). Machiavellian, bureaucratic, and transformational leadership styles in police managers: Preliminary findings of interpersonal ethics. Perception and Motor Skills, 86(2), 419-427. http://dx.doi.org/10.2466/pms.1998.86.2.419

Hackman, M. Z., \& Johnson, C. E. (2009). Leadership: A communication perspective (5 ${ }^{\text {th }}$ ed.). Long Grove, IL: Waveland Press.

Hair, J., Anderson, R., Tatham, R., \& Black, W. (1992). Mutlivariate Data Analysis with Readings (3rd ed.). New York, NY: Macmillan.

Hitt, W. D. (1990). Ethics and leadership: Putting theory into practice. Columbus, OH: Battelle.

Holladay, S. J., \& Coombs, W. T. (1993). Communication visions: An exploration of the role of delivery in the creation of leader charisma. Management Communication Quarterly, 6, 405-427.

Hood, J. N. (2003). The relationship of leadership style and CEO values to ethical practices In organizations. Journal of Business Ethics, 43(4), 263-273.

House, R. J. (1971). A path-goal theory of leader behavior. Administrative Science Quarterly, 16, 19-30.

Howard, G. S. (1994). Why do people say nasty things about self-reports? Journal of Organizational Behavior, 15, 399-404.

Jo, S., \& Shim, S.W. (2005). Paradigm shift of employee communication: The effect of management communication on trusting relationships. Public Relations Review, 31(2), 277-280. http://dx.doi.org/10.1016/j.pubrev.2005.02.012

Judge, T. A., Piccolo, R. F., Padsakoff, N. P., Shaw, J. C., \& Rich, B. L. (2010). The relationship between pay and job satisfaction: A meta-analysis of the literature. Journal of Vocational Behavior, 77(2), 157-167. http://dx.doi.org/10.1037/0021-9010.89.5.755

Kanungo, R. N., \& Mendonca, M. (1996). Ethical dimensions of leadership. Thousand Oaks: Sage.

Kassing, J. W. (2008). Consider this: A comparison of factors contributing to employees' expressions of dissent. Communication Quarterly, 56(3), 342-355. http://dx.doi.org/10.1080/01463370802240825 
Keyton, J. (2001). Communication research: Asking questions, finding answers. New York, NY: McGraw-Hill.

Kim, S. (2002). Participative management and job satisfaction: Lessons for management leadership. Public Administration Review, 62(2), 231-240.

Krimmel, J. T., \& Lindenmuth, P. (2001). Policy Chief performance and leadership styles. Police Quarterly, 4(4), 469-483.

Leech, N. L., Barrett, K. C., \& Morgan, G. A. (2005). SPSS for intermediate statistics: Use and interpretation. Mahwah, NJ: Lawrence Erlbaum.

Lee, J., \& Jablin, F. (1995). Maintenance communication in supervisor-subordinate work relationships. Human Communication Research, 22(2), 220-257.

Lussiez, Y. W. (2010). The empathic principal: The relationship between empathy, transformational leadership, and teacher self-efficacy. Unpublished doctoral dissertation, Univ. of New Mexico.

Madlock, P. (2008). The link between leadership style, communication competence, and employee satisfaction. Journal of Business Communication, 45(1), 61-78.

Meyers, L. S., Gamst, G., \& Guarino, A. J. (2013). Applied multivariate research: Design and interpretation. Los Angeles: Sage.

Mineo, F. P. (2009). An examination of the relationship between leadership styles and organizational sector culture for the emergency medical services leader (Doctoral dissertation). Retrieved from Dissertation Abstracts International (AAI3360077)

Minett, D., Yahman, H. R., \& Denizei, B. (2009). Leadership styles and ethical decision-making in hospitality management. International Journal of Hospitality Management, 28(4), 486-493.

Northouse, P. (2001). Leadership theory and practice. Thousand Oaks: Sage.

Redding, W. C. (1985). Stumbling toward identity: The emergence of organizational communication as a field of study. In R. D. McPhee \& P. K. Tompkins (Eds.), Organizational communication: Traditional themes and new directions (pp. 15-54). Newbury Park, CA: Sage.

Rubin, R. S., Bartels, L., \& Bommer, W. (2002). Are leaders smarter or do they just seem That way? Exploring perceived intellectual competence and leadership emergence. Social Behavior and Personality, 30(2), $105-118$.

Schnake, M. E., Dumler, M. P., Cochran, D. S., \& Barnett, T. R. (1990). Effects of differences in supervisor and subordinate perceptions of supervisors communication practices. The Journal of Business Communication, 27(1), 37-50. http://dx.doi.org/10.1177/002194369002700104

Snow, J. (2002). Enhancing work climate to improve performance and retain valued employees. Journal of Nursing Administration, 32(7/8), 393-397.

Spector, P. E. (1997). Job satisfaction: Application, assessment, cause, and consequences. Thousand Oaks: Sage.

Spreitzer, G. M., Kizilos, M. A., \& Nason, S. W. (1997). A dimensional analysis of the relationship between psychological empowerment and effectiveness, satisfaction, and strain. Journal of Management, 23(5), 679-704.

Teven, J., McCroskey, J., \& Richmond, V. (2006). Communication correlates of perceived Machiavellianism of supervisors: Communication orientations and outcomes. Communication Quarterly, 54, 127-142. http://dx.doi.org/10.1080/01463370600650829

Tompkins, P. K., \& Redding, W. C. (1988). Organizational communication - past and present tenses. In G. M. Goldhaber \& G. A. Barnett (Eds.), Handbook of organizational communication (pp. 5-33). Norwood, NJ: Ablex.

Tourish, D., \& Barge, J. K. (2010). An exchange of letters: What can a specifically social constructionist perspective bring to bear on what must be one of the most studied subjects in human history? Management Communication Quarterly, 24, 322-347. http://dx.doi.org/10.1177/0893318909359698

Walter, H. L., Anderson, C. M., \& Martin, M. M. (2005). How subordinates' Machiavellianism and motives relate to satisfaction with supervisors. Communication Quarterly, 53(1), 57-70. http://dx.doi.org/10.1080/01463370500056051 
Wanous, J. P., Reichers, A. E., \& Hudy, M. J. (1997). Overall job satisfaction: How good are single-item measures? Journal of Applied Psychology, 82, 247-252. http://dx.doi.org/10.1037/0021-9010.82.2.247

Warner, R. M. (2008). Applied statistics: From bivariate through multivariate techniques. Thousand Oaks: Sage.

Weber, M. (1946). Bureaucracy. In H.H. Gerth \& C.W. Mills (Eds. and Trans.), Essays in sociology. London: Oxford University Press.

White, J. B., Tynan, R., Galinsky, A. D., \& Thompson, L. (2004). Face threat sensitivity in negotiation: Roadblock to agreement and joint gain. Organizational Behavior and Human Decision Processes, 94(2), 102-124. http://dx.doi.org/10.1016/j.obhdp.2004.03.005

\begin{abstract}
Notes
${ }^{1}$ Our decision to use single-item measures of these two variables was based on several factors. First, since we were interested in global opinions about supervisor effectiveness and relational satisfaction, rather than the specific components that may contribute to those opinions, we used the simplest, overall measure of the construct (Bernard, 2000; Wanous, Reichers, \& Hudy, 1997). Secondly, previous research has successfully utilized this method for summary purposes which enabled us to create a more parsimonious instrument in an effort to increase our overall response rate (Dillman, 2000).

${ }^{2}$ Warner (2008, p. 198) notes that in non-experimental group comparisons, "subjects need to be chosen so that they are different enough to show detectable differences in outcome." This method enabled us to compare the top third with the bottom third on this global assessment and is consistent with other published research (White, Tynan, Galinsky, \& Thompson, 2004). Use of this methodology for creating discrete groups required the use of a Bonferroni correction for a more conservative alpha of $\mathrm{p} .<.01$. The potential problem of attenuation was clearly not an issue here since all the t-test findings were statistically significant below that level.
\end{abstract}

\title{
Appendix
}

Communication Behaviors (Costigan \& Schmeidler, 1984)

\section{Sample Defensive Communication Items}

Evaluation:

My manager criticizes my work without allowing me to explain.

Control:

My manager needs to be in charge of situations.

Strategy:

My manager tries to manipulate employees to get what he/she wants.

Neutrality:

My manager does not seem interested in employee problems.

Superiority:

My manager often tries to make employees feel inadequate.

Certainty:

My manager is dogmatic.

\section{Sample Supportive Communication Items}

Description:

Problem Orientation:

Spontaneity:

Empathy:

Equality:

Provisionalism:
My manager tries to explain situations clearly and without personal bias.

My manager seeks employee input on problems and issues.

My manager does not have hidden motives in dealing with employees.

My manager respects my feelings and values

My manager treats me as his/her equal.

My manager allows flexibility on the job.

For a more detailed description of the questions utilized in the instrument see Czech and Forward (2010).

\section{$(\infty)$ EY}

This work is licensed under a Creative Commons Attribution 3.0 License. 